\title{
Documentation of a Native American Church Altar in Caddo County, Oklahoma
}

Robert Cast

Unknown

Follow this and additional works at: https://scholarworks.sfasu.edu/ita

Part of the American Material Culture Commons, Archaeological Anthropology Commons, Environmental Studies Commons, Other American Studies Commons, Other Arts and Humanities Commons, Other History of Art, Architecture, and Archaeology Commons, and the United States History Commons

Tell us how this article helped you.

This Article is brought to you for free and open access by the Center for Regional Heritage Research at SFA ScholarWorks. It has been accepted for inclusion in Index of Texas Archaeology: Open Access Gray Literature from the Lone Star State by an authorized editor of SFA ScholarWorks. For more information, please contact cdsscholarworks@sfasu.edu. 
Documentation of a Native American Church Altar in Caddo County, Oklahoma

Creative Commons License

(C) $(1) \Theta$

This work is licensed under a Creative Commons Attribution-NonCommercial 4.0 International License 


\section{DOCUMENTATION OF A NATIVE AMERICAN CHURCH ALTAR IN CADDO COUNTY, OKLAHOMA}

\section{Robert Cast}

\section{An Archaeological Perspective}

What little research that has been done in Caddo County, Oklahoma (and elsewhere) with Caddo Native American Church altars or "fireplace" locations show that there is a desperate need to document and record these locations for future generations. However, even with the paucity of this research, it is feasible to suggest that these ceremonial altars, their stylistic differences, and the passing of this religion to future generations of traditional practitioners have had a very long history (Miller 1996).

Others have discussed the ceremonial uses of fire, structures, objects, and mounds in the archaeological record (Kay and Sabo 2006: 33, Lankford 1987: 54-55), yet have not addressed the appearance and importance of these uses extending into the historic era and their continued use in present day religious rituals among the Caddo peoples. If, according to these researchers, "the prominent role fire and the central hearth played" are "symbols of life itself," then I suggest that these symbols of life must be manifested in some form in present day ceremonial uses.

Some researchers go so far as to suggest "in leaving little to chance, these people [in referring to those living at the Harlan site, 34CK6] combined tangible elements of their material world with performance in acting out an ordered structure of belief" (Kay and Sabo 2006:30). These belief systems, then, become a large part of the physical and archaeological record left behind, but not only this, many of these belief systems of the past have been carried on in the present through the peyotism ceremonies of the Native American Church.

In studies of the historic Caddo, it is not unlikely that similar altars could be found in areas such as the Brazos Reserve on the Brazos River in Young County, Texas, Caddo Lake, and Timber Hill (41MR211), an early $19^{\text {th }}$ century Caddo village near Caddo Lake, as well as other pre-1859 Caddo sites across eastern Texas. Moreover, similar altars may never have been accounted for in the archaeological record of these areas, as archaeologists working in these areas may have been unaware of what was being observed, its particular use, and unknowingly failed to record them as significant in any way. Furthermore, the ceremonial altars themselves could have been a part of the natural landscape, thus making identification of these places extremely difficult.

\section{Documentation of a Native American Church Altar}

On April 21, 2006, the Cultural Preservation Department of the Caddo Nation of Oklahoma visited a historic Caddo cemetery on the Peter Williams (b. 1876, d. 16 Sept. 1935) Allotment with descendants of Peter Williams to gather information for recordation of both the house place and cemetery. In the process, we were informed of a 
traditional cultural property of the Caddo Nation, a Native American Church peyote ceremonial altar that was buried just below the surface of the ground near the northwest corner fence-line bordering the yard around the house (Figure 1).

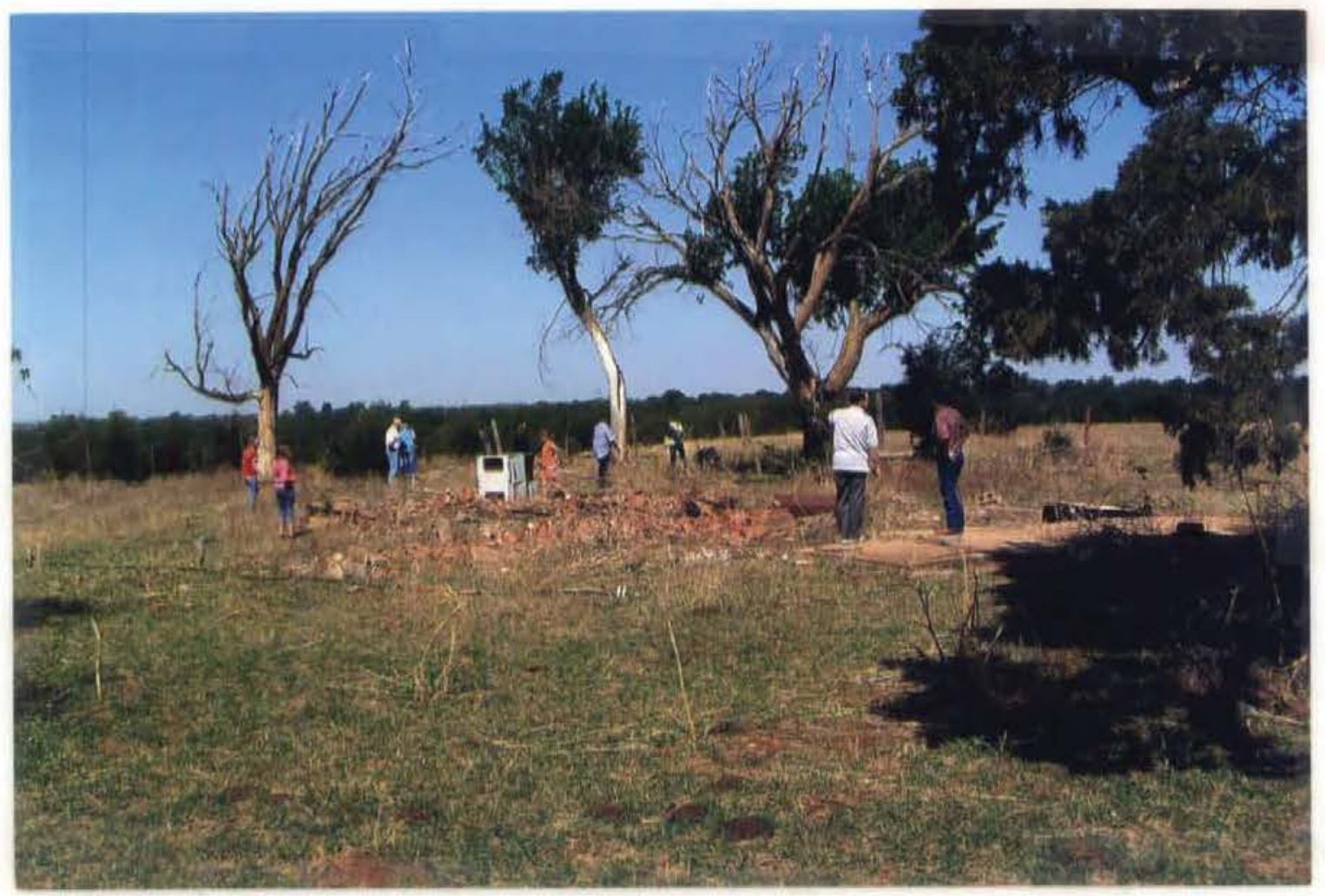

Figure 1. Peter Williams house place.

The house structure is no longer standing. However, there is an apparent house place with scattered red bricks, cement foundations for both the house and outbuildings, a cook stove, metal plumbing pipes, and other household debris at this place.

During our visit, the informant mentioned that as a little girl, she remembered an odd cement anomaly located near to the house. Years later, she came back to this spot on the northwest corner of the fence and began probing around to see if she could find the cement again. Her motive was to take something back home with her to Utah from her childhood home. She soon realized that the object was far too big, and she covered it back over before leaving. She showed us the location of the cement feature, and we began uncovering it and immediately recognized it as a ceremonial Native American Church altar.

On the castern end of the altar, incised into the cement, is a "heart" (Figure 2). At that time, it was not feasible for us to record the altar, as we were there to record the family cemetery (Figure 3 ). 


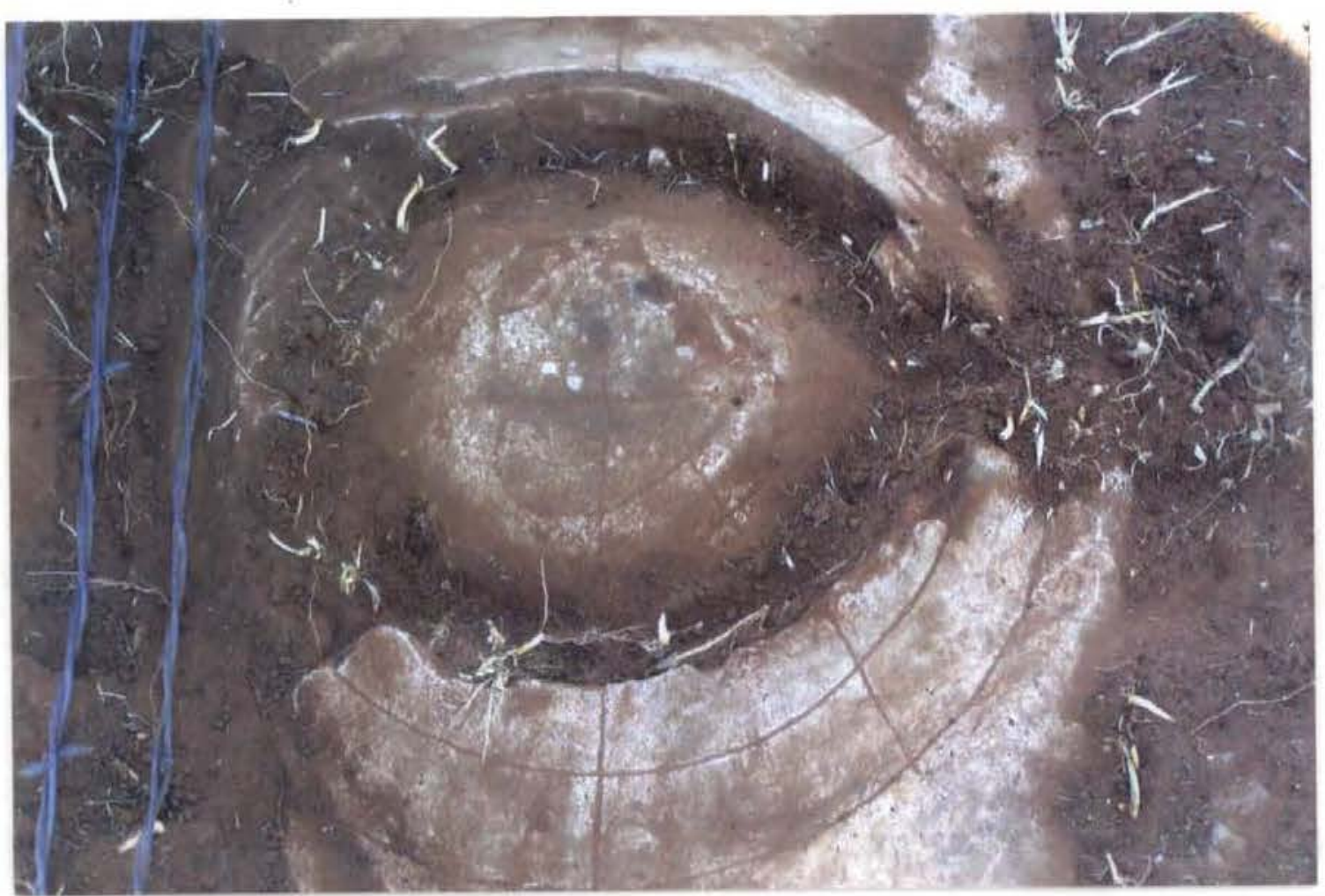

Figure 2. Cement "heart."

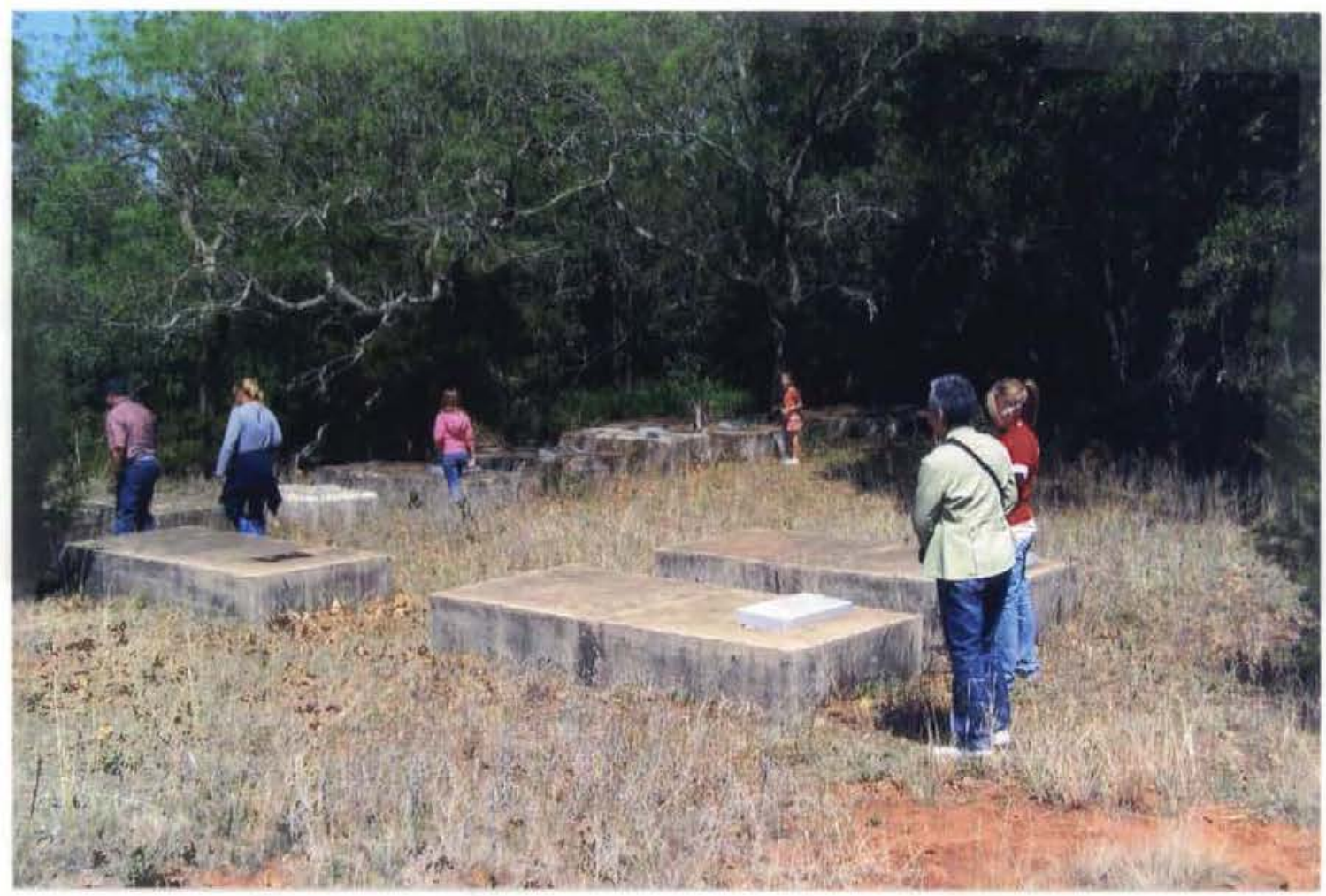

Figure 3. Peter Williams family cemetery. 
Bobby Gonzalez and I returned to the place on May 18, 2006, and began clearing the soil matrix off of the top of the altar. The altar had been covered by approximately 5 to 10 centimeters of soil (Figure 4). We created some brief sketch maps of the altar (Figure 5) and took measurements of the altar (Figures 6-9).

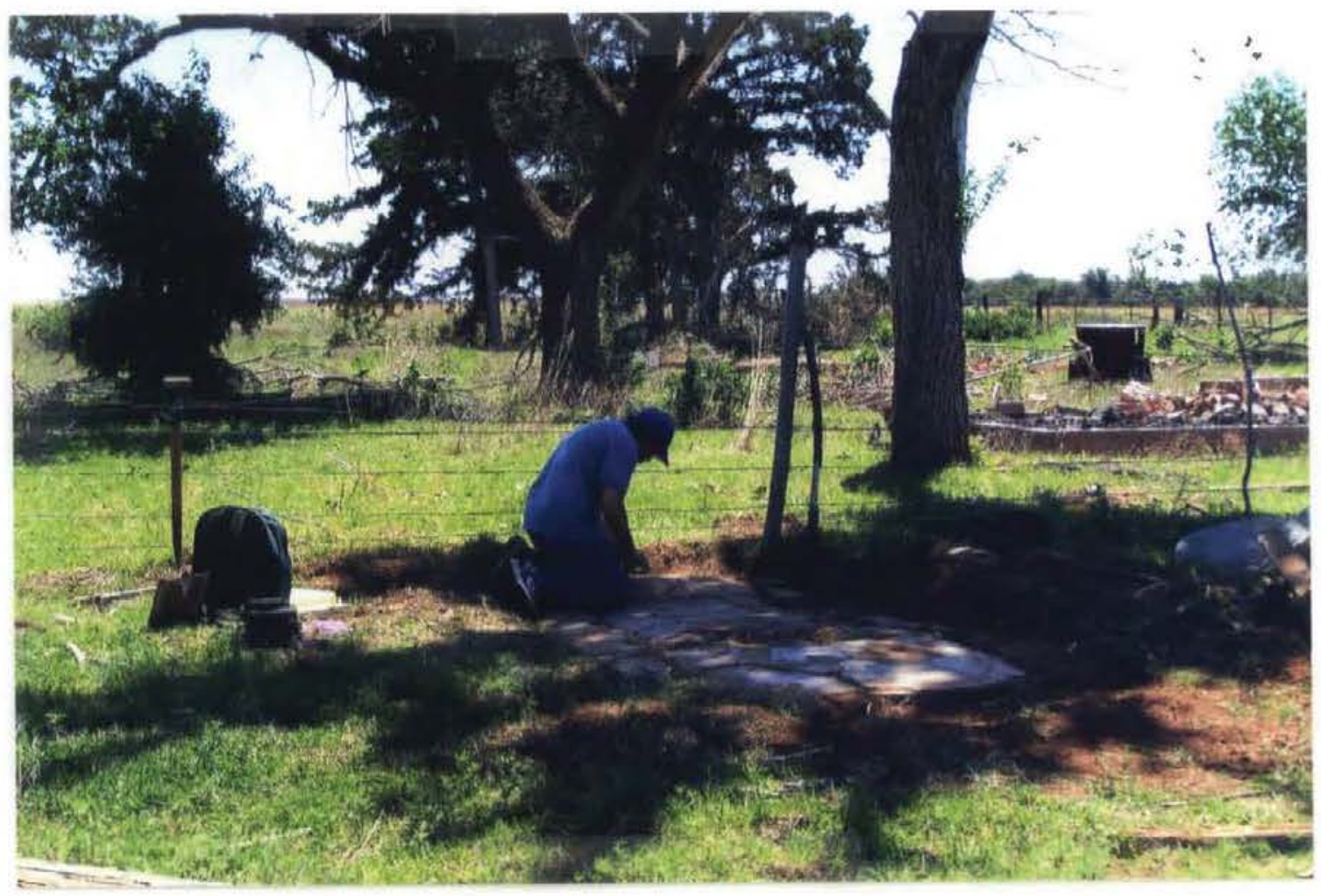

Figure 4. Bobby Gonzalez cleaning off the altar. 


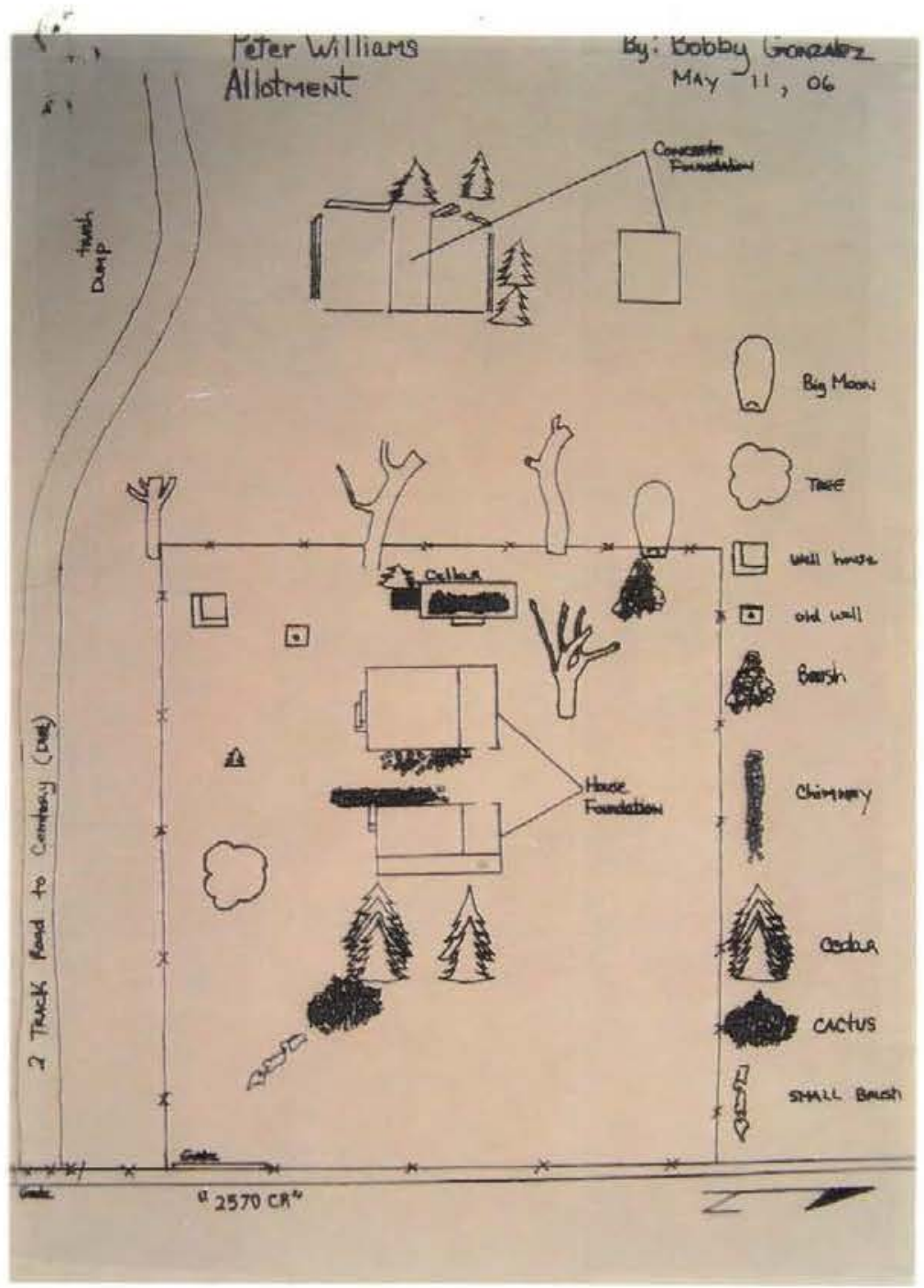

Figure 5. Overview of the Williams Place. 


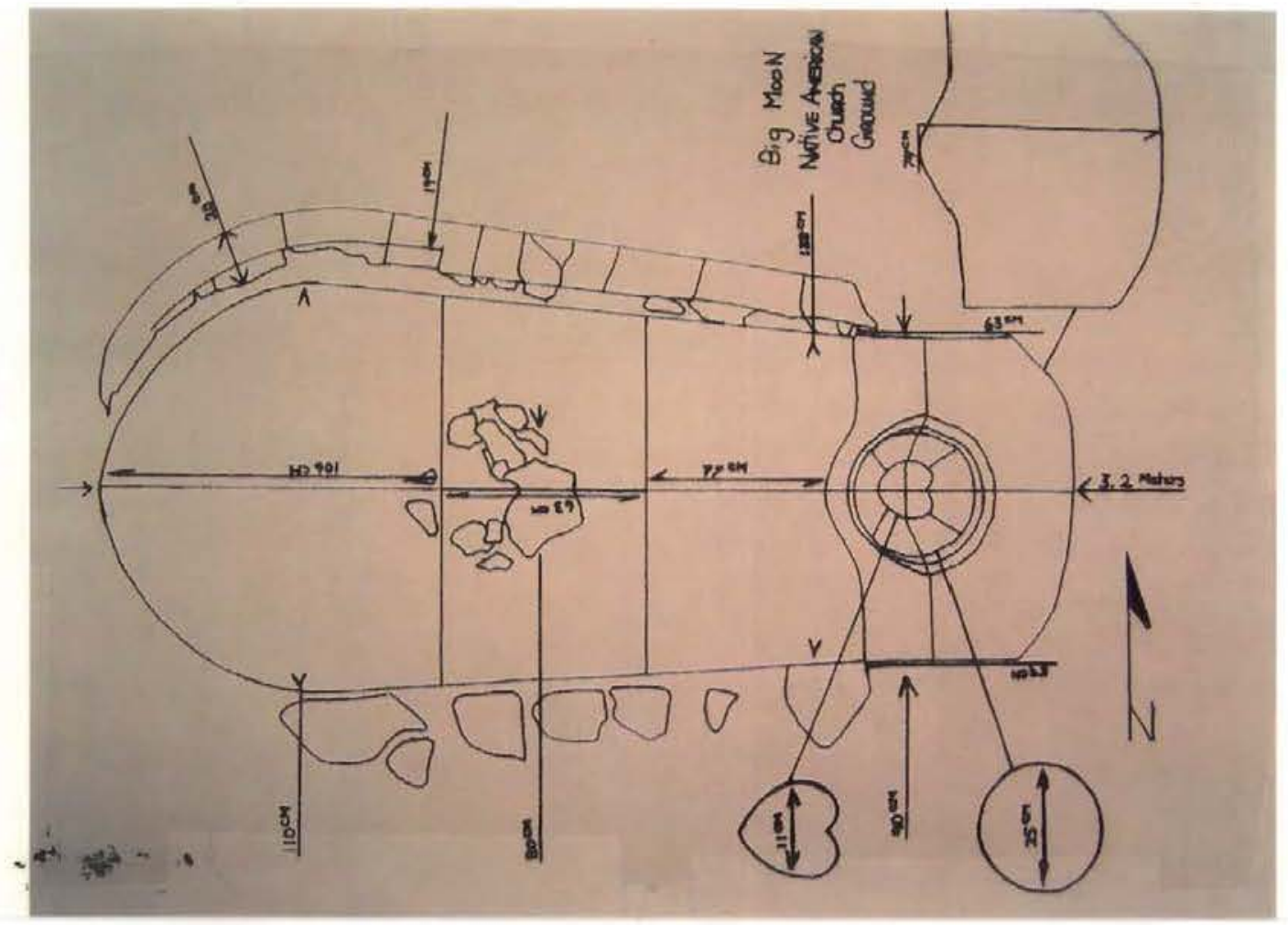

Figure 6. Detail of the altar.

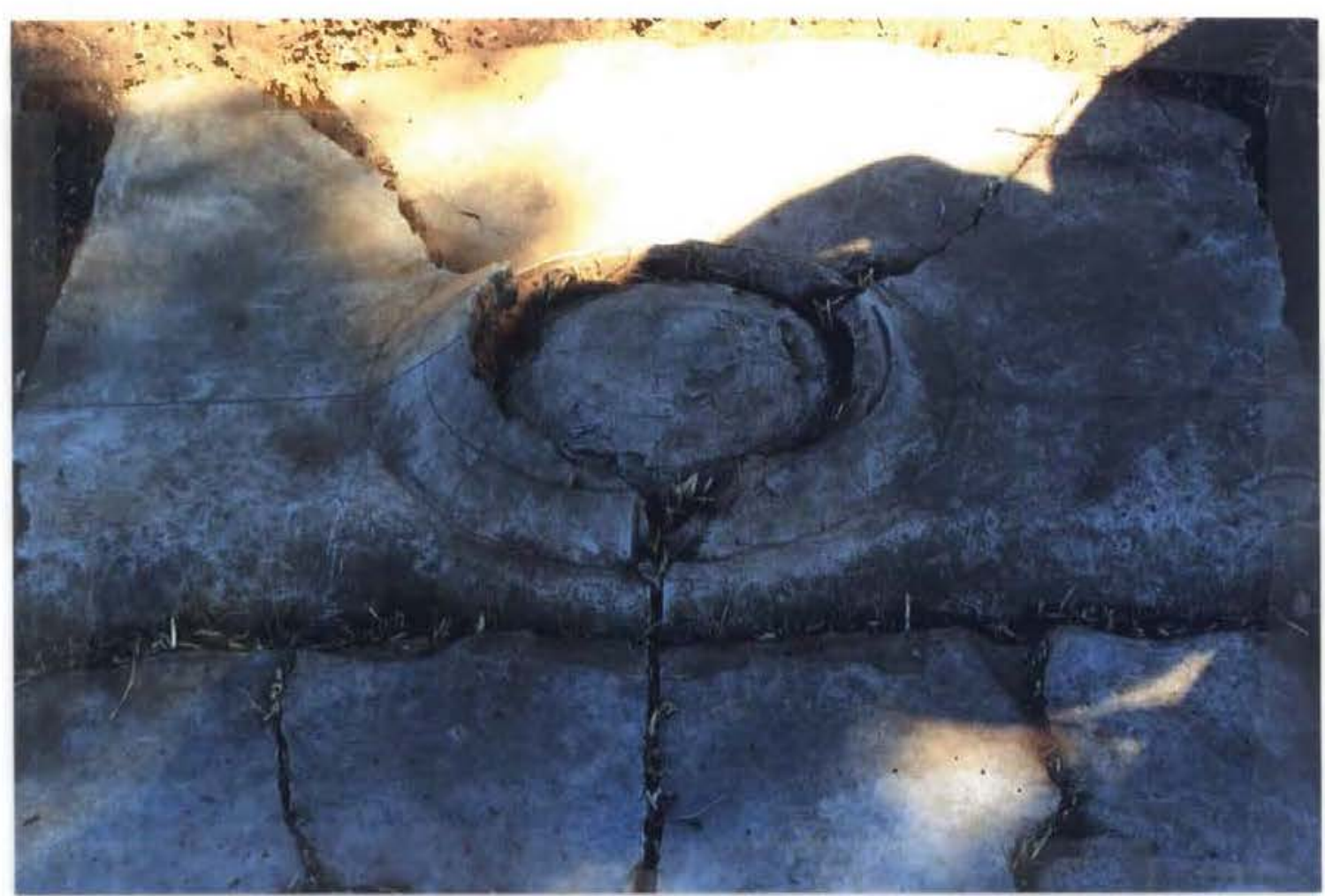

Figure 7. East end of the altar 


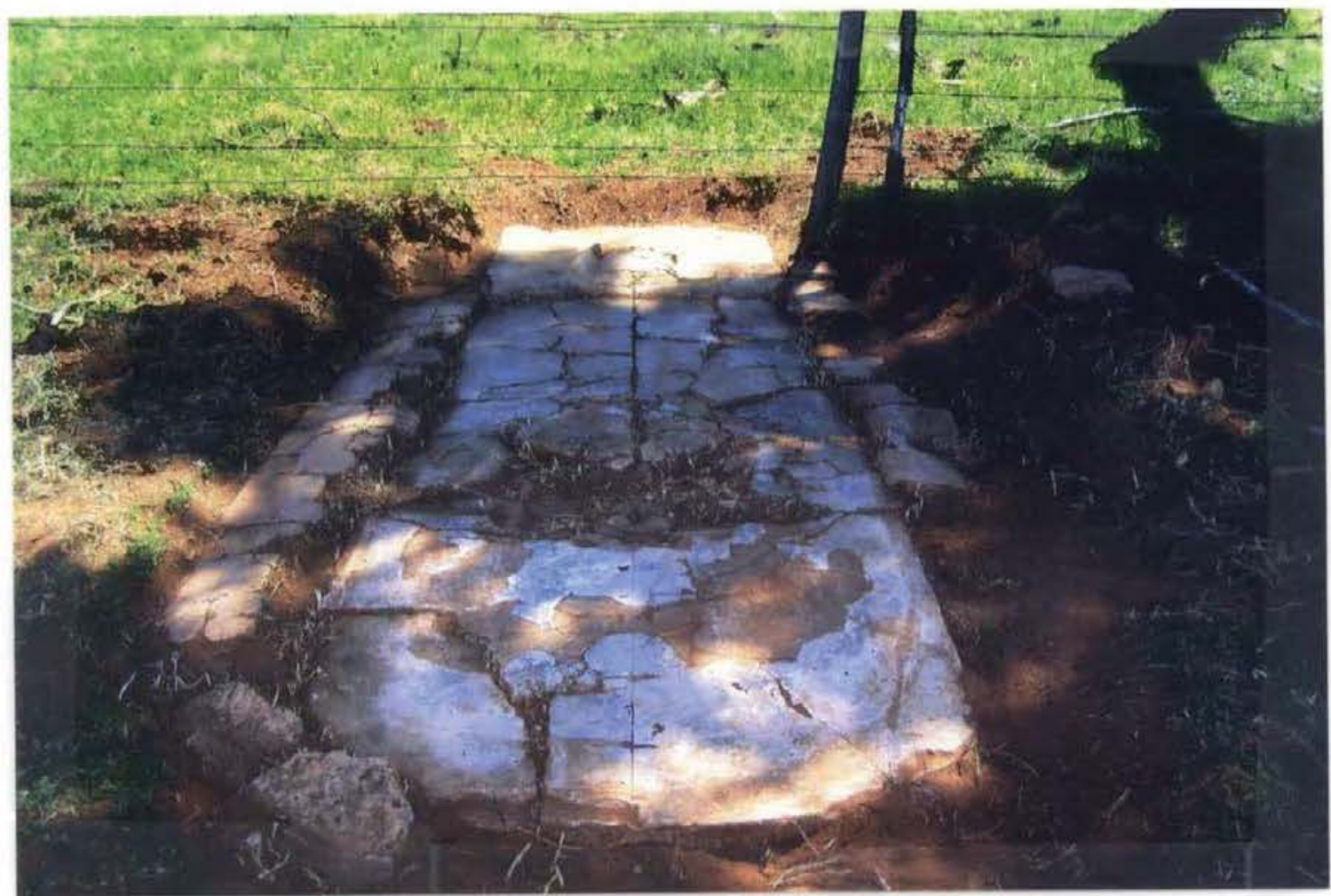

Figure 8. Overview of the altar, looking east.

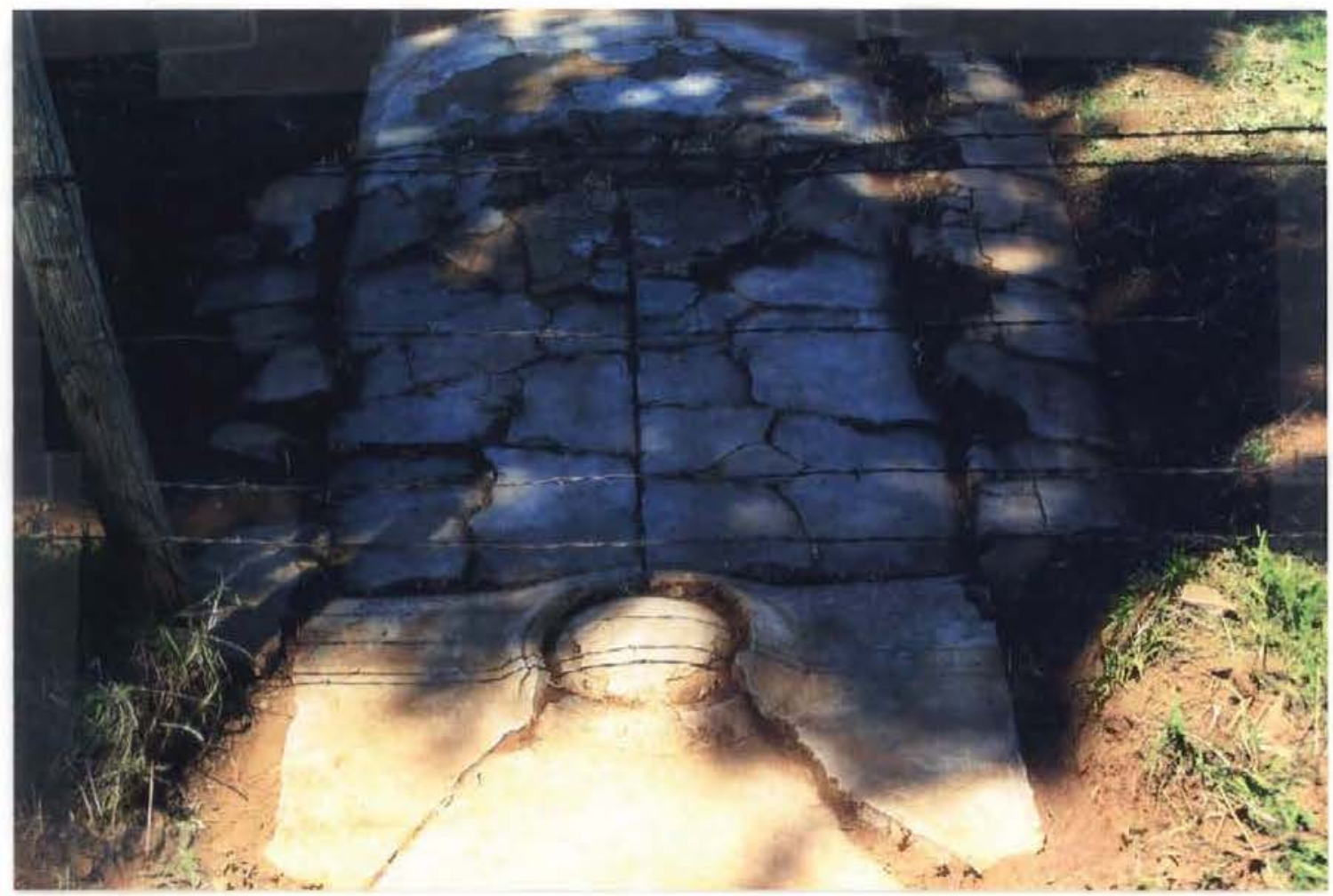

Figure 9. Overview of the altar, looking west. 
From information we have gathered pertaining to this particular altar, we found that this is considered a "Big Moon" altar of the Native American Church and that this altar was probably in use at least 70 years ago. Two informants, both Native American Church practitioners, without prior corroboration, stated that this altar was most likely last used by Francis Williams. One of these informants, in his early 70 s, stated that he could remember a meeting held there when he was a small child in his pre-teen years. He further stated that Mr. Williams was his uncle and was a very well respected Caddo peyote man for his time in the Caddo County area. If this is indeed the case, the peyote altar could have been in use in the 1930s. Further investigations regarding both Mr. Williams' genealogy, and reliable independent dating methods, are needed to further refine the age of the altar.

There are approximately three other known Native American Church peyote altars that have been recorded in the area. One is between the towns of Gracemont and Anadarko, built into a hillside. It is considered a sacred site of the Wichita Nation; however, many of the tribes in the area jointly used the altar. Erosion has taken its toll on the altar at present, and any markings that were once there are only vaguely perceptible. Duane Kendal Hale, author of Peacemakers on the Frontier: A History of the Delaware Tribe of Western Oklahoma, notes that Dr. Jay Miller recorded an altar in the Keechi Cemetery in 1986 (Hale 1987:183). This particular altar is purported to have been set in cement in 1947 and is referred to as the "Willie Thomas Fireplace" (Hale 1987: 203). However, this "fireplace" is very different than the Francis Williams example (Figures 10-13).

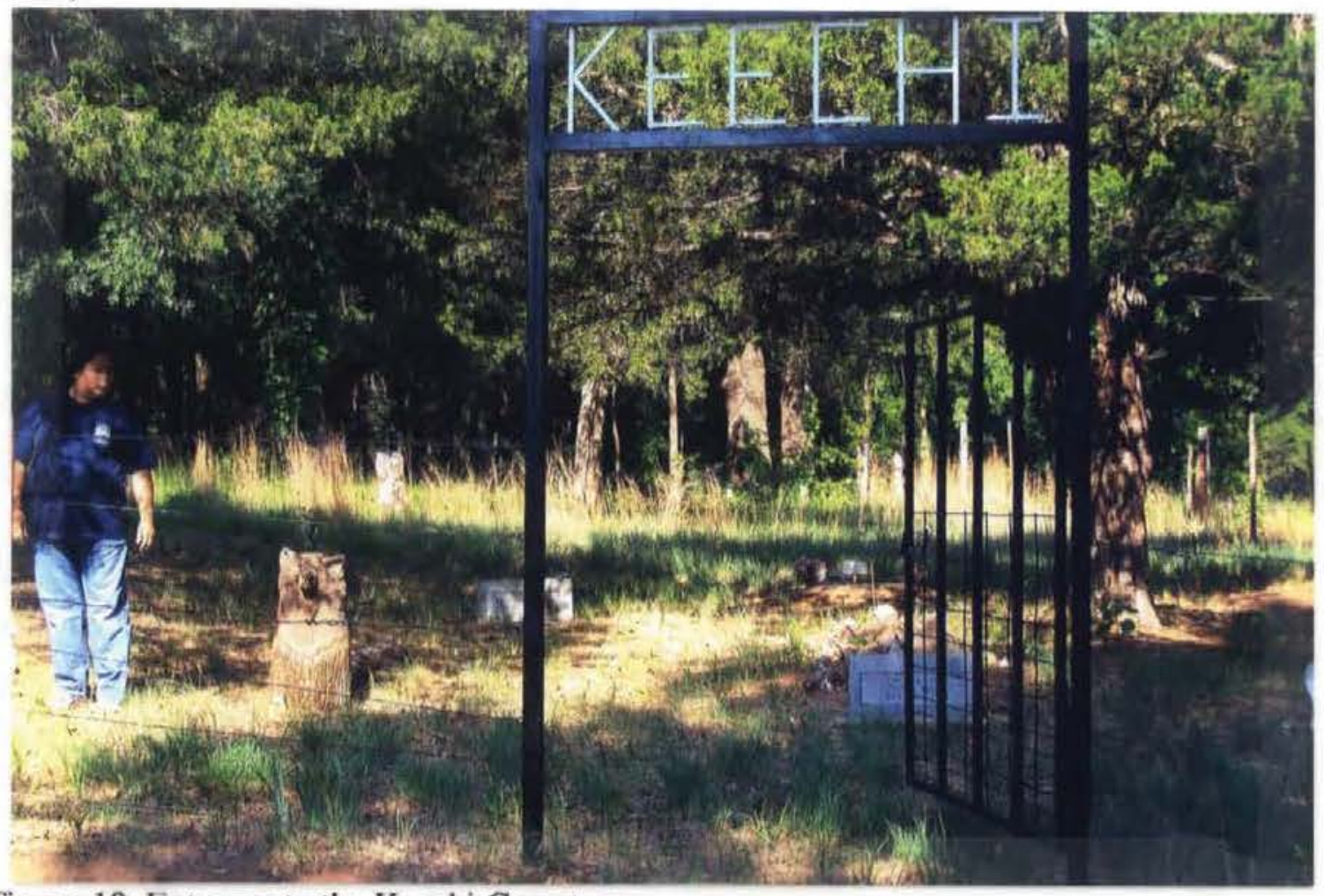

Figure 10. Entrance to the Keechi Cemetery. 


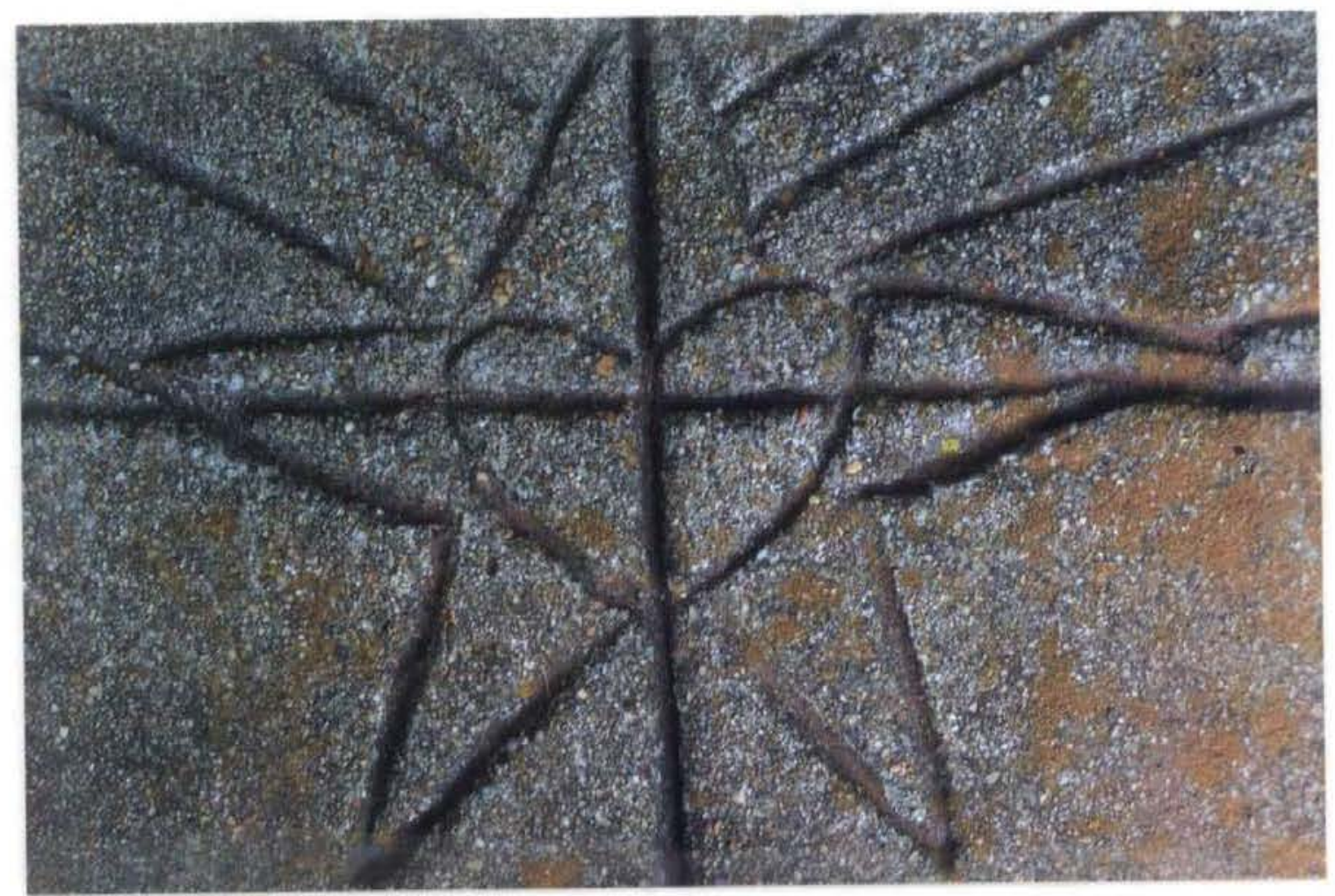

Figure 11. Detail on the altar.

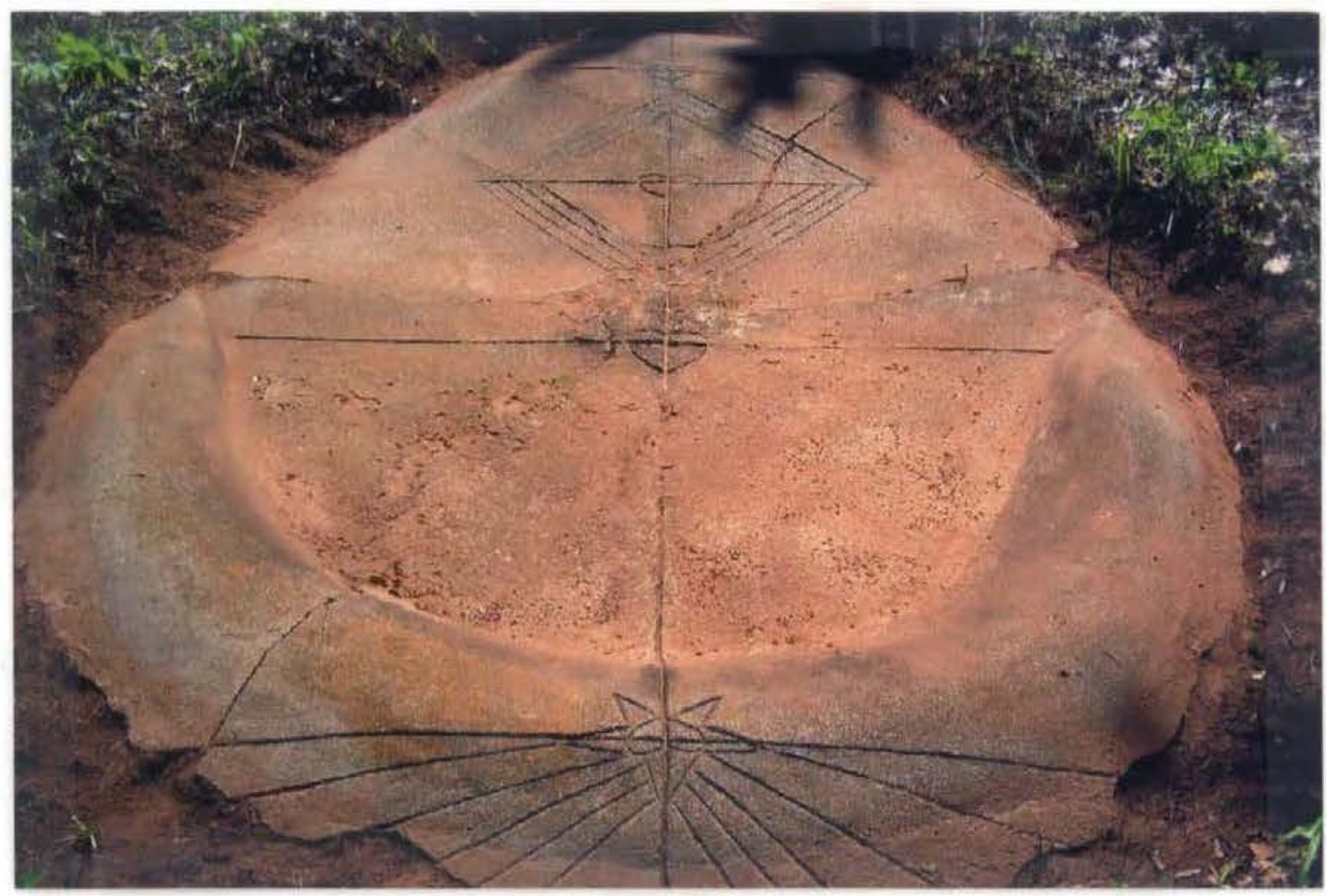

Figure 12. Overview of the "Willie Thomas" altar. 


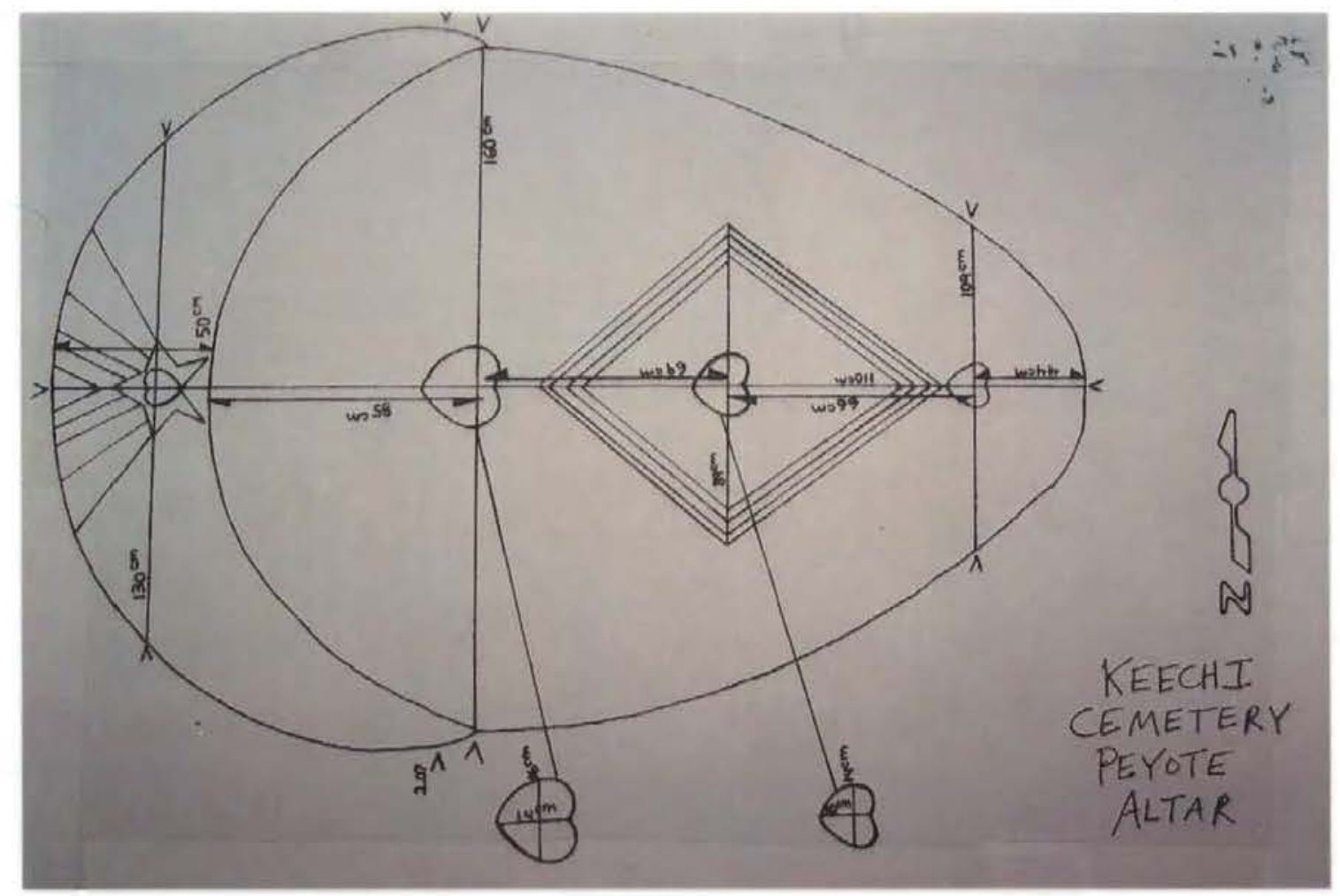

Figure 13. Map of the "Willie Thomas" altar.

Another ceremonial altar is near Washita, Oklahoma. This altar has been termed the "Enoch Hoag, Sr. Fireplace" (Hale 1987). There is no information available concerning this particular altar at present but plans have been made to make visits in the future to compare this altar to those others known in the area.

The two previous examples discussed above have been referred to as "half-moon" style altars. There is also little known about the altar placed in the natural landscape and more research is needed to determine when it may have been used.

\section{References Cited}

Hale, D. K.

1987 Peacemakers on the Frontier: A History of the Delaware Tribe of Western Oklahoma, Delaware Tribe of Oklahoma Press, Anadarko, Oklahoma.

Kay, M. and G. Sabo III

2006 Mortuary Ritual and Winter Solstice Imagery of the Harlan-Style Charnel House, Southeastern Archaeology 25 (No. 1):29-47. 
Lankford, G. E.

1987 Southeastern Legends: Tales from the Natchez, Caddo, Biloxi, Chickasaw, and Other Nations. August House, Little Rock, Arkansas.

Miller, J.

1996 Changing Moons: A History of Caddo Religion. Plains Anthropologist 41 (No. 157) 243-259. 